\title{
Does Socio-Economic Status matter for Greater Political Participation of Women: A Comparative Study between Australia and Bangladesh in Light of the Modernization Theory?
}

\author{
Fardaus Ara \\ Professor, Department of Public Administration, University of Rajshahi, Rajshahi, Bangladesh \\ *Corresponding Author \\ Fardaus Ara
}

\author{
Article History \\ Received: 13.06 .2020 \\ Accepted: 20.06.2020 \\ Published: 25.06.2020
}

\begin{abstract}
Proponents of Modernization theory claim that modernization brings greater gender equality in all sectors of society including politics. However, globally women are marginal in all spheres of politics regardless of the level of modernization within countries. There is no country either developed or developing that has ensured equal participation of women in politics. This comparative study aims to analyze the status of women as elected representatives in Australia and Bangladesh. It finds that with few exceptions, women in Australia and Bangladesh have to overcome similar barriers to their participation in elected office. Furthermore, the similarity in issues facing women entering politics in both countries, despite tremendous cultural and socio-economic differences, indicates that the barriers appear to relate to universal challenges to participation of women in politics, more specifically to patriarchal structures and values.
\end{abstract}

Keywords: Australia, Bangladesh, modernization, political participation, women.

\section{INTRODUCTION}

Women comprise a little more than half of the world population. Although they have contributed a lot in the social and economic development of societies, their participation in formal political structures and processes remains insignificant [1]. Worldwide, women are marginal in politics, and this is true regardless of the level of socio-economic development within countries. The study tries to explore the status of women in formal representational politics in the context of modernization using Australia and Bangladesh as the cases.

Classical sociological theorists like Verba and Nie [2], Wolfinger and Rosenstone [3] claim that participation of women in politics increase due to economic modernization and development. According to them two significant aspects of development are higher material wealth and higher levels of education. These are connected with increased support for democracy, social spending, and a societal push that ultimately results in the emancipation of women [4].

Modernization classifies societies as either traditional or modern, with gender disparities tending to be linked with traditional societies. The Western industrialized nations are considered as closer to an ideal contemporary egalitarian treatment for women. The rights to vote, participating in election for political office, and personal property are regarded as indications of rising equality of women in the Western world. The extension of these rights indicates an improved shift in women's position. So, societies closer to the Western prototype and standard are portrayed as beneficial to women [5]. They argue that increased economic development accompanied by a more extensive provision of educational and professional resources heighten women's opportunity for professional development, generating a superior pool of women eligible to serve the political office. Others scholars like (Kenworthy \& Malami; Reynolds; and Rule) argue that higher levels of economic development allow more social amenities to assist women in society, as the expenses of labor and time of child-rearing and household work decrease and consequently women get more free time for social activities [6-8].

Copyright @ 2020: This is an open-access article distributed under the terms of the Creative Commons Attribution license which permits unrestricted use, distribution, and reproduction in any medium for non commercial use (NonCommercial, or CC-BY-NC) provided the original author and source are credited. 
Inglehart, Norris and Welzel explain the impact of modernization (especially economic development) on political participation of women and democracy. They identify culture as a crucial factor accounting for women in political leadership positions in a wide variety of countries with unstable political systems and degree of economic development. However, they demonstrate that egalitarian attitudes towards women in political office are more dominant in post-industrial societies, reflecting broad patterns of socio-economic development and cultural modernization. The researchers claim that economic development directs towards change in a society's culture that helps to develop selfexpression values, and consequently gender parity increases [9].

Academics who concentrated on the impact of development on women discovered just positive outcomes. Industrialization was viewed to lessen the social consequences of biological irregularity amongst men's and women's physical ability; birth control was said to free women from the vast cycle of uncontrolled reproduction; and modern values and anticipations were predicted to enhance women's rights and autonomy to act [10]. However, there are controversies among academics regarding the assumption that modernization leads to gender equality in society.

\section{Methodology}

The article aims to explore if the socio-economic and political backgrounds of women in the two countries differ? If so, how do the differences influence their participation as elected representatives? Furthermore, it will identify the barriers to the political participation of women in the two countries considering the similarities or differences in the context of modernization. In doing so, data has been collected through semi-structured interviews with 42 elected female representatives at the parliamentary and local government level in Australia and Bangladesh. Additionally, secondary data for this research has been collected from published and unpublished materials, books, journals, reports, newspapers, basic legal documents, and government policy papers relevant to the study and also from the Internet.

\section{Women in Electoral Politics in Australia and Bangladesh at a Glance}

Women in both countries fail to form a critical mass as parliamentary members, party leaders, ministers, mayors and local government councilors. The percentage of women in the parliament of Australia (28.7\% in the Lower House and $40.8 \%$ in the Senate) and Bangladesh $(20.3 \%$ ) shows that regarding the share of women in the parliament there is not a significant difference between the countries [11]. In the local government, women comprise $28.1 \%$ of elected representatives in Australia, against 26.6\% elected councilors in Bangladesh [12]. However, the fact that most of the female politicians in Bangladesh are elected to reserved seats through a quota system makes such comparisons quite meaningless. A better indicator for comparative purposes is the number of women elected to general seats, and in this regard, Australia is far ahead than Bangladesh in terms of gender parity in politics. In the 2008 parliamentary election of Bangladesh, 19 women were elected to the general constituencies whereas 20 females won in the 2014 parliamentary election, occupying $6.3 \%$ and $6.7 \%$ of the parliamentary seats respectively [13].

\section{Socio-Economic Background of the Female Participants Age of the Women Participants}

Age is a key contributing factor to political activity. With maturity, people become more involved with their communities through long-term residency, parenthood, life experience, and the like, which lead them to take a greater interest in the community and national interests. These wider interests result in greater levels of participation. Therefore, women may have their political activity level increased with age [14]. It is found from the interviews that over half of the Australian participants were elected to federal parliament during their 40s and 50s, with the average age being 42.2 years. In Bangladesh, three women in the national politics were in their $30 \mathrm{~s}$, and four were in their 40s, with the mean age of participants being 45.1 years, slightly higher than in Australia.

In local government eight of the Australian participants were in their 40s and 50s, with the mean age of entry being 52.7 years. Among the Bangladeshi participants, eight women were under 40 years, with the average age being 35.1 years, which is considerably younger than their Australian counterparts.

From the available data on the parliamentary websites of Australia and Bangladesh, it is found that the mean age of female parliamentarians in Australia when first elected to federal parliament during the period 2013-2016 was 43.4 years [15] and for Bangladesh (members from 2014 to onward) the average age was 46.7 years [13]. The data indicates that the participants of the study correspond with the average age of the female representatives' first entry in national parliament. It is quite difficult if not impossible to calculate the average age of the female local government representatives in the two countries as the number is quite large. However, a United Nations Economic and Social Commission for Asia and the Pacific [UNESCAP] study in 2001 finds that most female urban local government representatives in Australia are in the 41-50 age group [16] and in Bangladesh, it is 31-40 age group [17]. The age of the local government participants in Australia and Bangladesh of this study matches the UNESCAP findings. 
One explanation for women who join the local government in Western Australia tend to be more senior in age is possibly the perception that local government is less considered a political career and more as a voluntary service. Indeed, the elected representatives do not get a salary. Like Australia, local government in Bangladesh is less political and competitive than national politics. However, women in Bangladesh do not participate to the same degree as Australian women in professional careers, so they become more free at an earlier age to get involved in local government. As the local government is closer to their house, and most of them have extended families, it is easy to get assistance from other family members. Thus, interested women can join the local government in Bangladesh at a comparatively young age, as it does not interfere much with their domestic responsibilities, like child-rearing. Furthermore, there are one-third reserved seats particularly for women that make it easier for women to contest in local government in Bangladesh.

\section{Education of the Women Participants}

Education is an essential component of political participation because it helps to enhance participation to a lesser or greater degree by developing important skills such as reasoning and communication skills, helpful for public debate and to interact in a political organizational setting efficiently and confidently [18]. Finally, education gives people the opportunity to exercise leadership, develop civic skills of cooperation and negotiation, and achieve bureaucratic and organizational expertise helpful for political action [19].

It is found that women in Australia, in general, are well educated. Conversely, while in Bangladesh female politicians at the national level are highly educated, in local government six of the female participants have not attained a tertiary education. Only one of the local government participants is highly educated, and three others have tertiary degrees. In the education sector, there is a wide gap between these two countries that can be explained as the impact of modernization in these societies.

Interviews with the participants revealed that in Australia, all the elected women representatives both at the federal and local government completed tertiary level of education with either a diploma or university degrees. From the available information on the Australian parliamentary websites, it is found that among the members and senators (during 2013-2016), 41 have completed their graduation, 15 have masters, two have diplomas, three have completed high school, and one was enrolled in university but did not complete [15].

In the national parliament in Bangladesh, the women participants are highly educated; two with PhDs, six with master degrees and two have completed high school graduation. However, for locally elected women participants in Bangladesh, the picture is quite different as at the local level only five of the women participants have graduated from high school while another one completed primary school. Among the female MPs in the $10^{\text {th }}$ parliament of Bangladesh, two have PhDs, one has an MBBS degree, 25 have masters degrees, 26 have bachelor degrees, seven have completed HSC (class/grade XII), six have completed SSC (class/grade X), two have completed class/grade VIII, and three are selfeducated [13]. It is seen that like the national level participants of the study, most of the female MPs in Bangladesh parliament are highly educated. In general, it is found that women in local government in Bangladesh are not highly educated like women in national parliament that can be explained as the different level of modernization between urban and rural areas within the country.

The level of education of the interviewees is a reflection of the different educational status of women in the respective societies. The literacy rate in Australia is $99 \%$ for men and women; $98 \%$ women and $97 \%$ of men having enrolled in primary education; $88 \%$ women and $86 \%$ of men having enrolled in secondary education; and $72 \%$ of men and $102 \%$ of women having enrolled in tertiary education. In contrast, in Bangladesh, the literacy rate for women and men is $58 \%$ and $65 \%$ respectively; primary education enrolment rate is $92 \%$ for women and $88 \%$ for men; secondary education enrolment rate is $55 \%$ for women and $50 \%$ for men; and, tertiary education enrolment rate is only $11 \%$ for women and $15 \%$ for men [20].

The lower level of education for women at local government in Bangladesh can be explained as due to traditional attitudes of favoring men that means less attention and importance is given to women education. In Bangladesh, a large number of girls generally get married just after finishing their primary or secondary education. After marriage, the majority of them fail to continue their studies because of non-cooperation from their husbands and in-laws. Conversely, women participating in national politics mostly come from rich, powerful and educated families with high social status, so they are in a better position than those participating at the local government. Moreover, the education policy of the Government of Bangladesh also has an impact on the lower level of education for women as primary school is free and compulsory for all, but not so for high school. So after completing the primary school, many parents do not send their girls to high school due to financial insolvency. If they can afford an education for only some of their children, the preference is given to male child [21]. 


\section{Marital Status of the Women Participants}

It is traditionally assumed that the influence of marriage has an adverse effect on women's political participation as household obligations, including child-care, and usual sex roles discourage women from getting involved in politics [14]. Besides, women in traditional family structures would be secluded from political organizations in one way or another owing to their lack of access to resources like time, finance, contacts, channels of communication, and the general expertise that are effective for participation [22]. However, family arrangements differ across societies and cultures.

Among Australian federal participants, five are married, four are in de-facto relationships, two are single, and one is divorced. Available data in the Australian parliamentary websites on women MPs and Senators (2013-2016) shows that 42 are married, 12 are living with a partner, four are single, and four are divorced or separated. It is seen that women are in various forms of marital relationships [15]. In the case of local government, four are married, two are divorced, two are widowed, one is in a de-facto relationship, and another one is separated. Like the national level, participants at local government are in different forms of marital relationships.

In Australia, marriage has experienced significant change throughout the years. In the 2001 Census, $52 \%$ of all people over the age of 15 were married, and a further $16.5 \%$ had been married but were now widowed, divorced or separated. While the majority of people marry sooner or later in their life, the likelihood of marriage is reducing, and the extent of a person's matured life spent as a married person is declining. The crude marriage rate per 1000 people was 6.1 in 1995, which reduced to 5.2 in 2014. Both men and women often live together before getting married, many do not marry at all, those that decide to marry are doing so later in their lives, and others get married more than once [23]. Living together prior to marriage is increasing, with $81 \%$ couples living together before marriage in 2015, an increase from the $79.4 \%$ recorded in 2014. The median age at marriage for males in 2015 was 31.8 years and for females was 29.8 years, and the percentage of remarriages for both partners stands at $11.7 \%$ in 2015 [24].

In politics sometimes marital status is used as a tool by the opponents to criticize women, especially if the woman is standing for a major political position; as the incident took place during the 2010 election campaign where Julia Gillard's marital status was a focus of media and commentary. Ms. Gillard was living in a de-facto relationship. The conservatives criticized her harshly for not being married and not having a family [25].

Among Bangladeshi parliamentary participants, eight are married while one is a widow and another one is single. The available marital status of female national parliamentarians gives the picture that in the $10^{\text {th }}$ parliament $67.6 \%$ female MPs are married, 25.4\% are widows, and 7\% are single [13], which roughly corresponds to marital rates in the wider society. For local government participants, a similar trend is found.

In Bangladesh, marital status is quite significant for a person's status and professional advancement, more specifically if the individual is a woman. Although marital responsibilities can impede women if they live in an extended family, husbands and in-laws can serve as a source of political connections and inspiration for them. Shamim and Kumari [26] note that in a traditional male-dominated society like Bangladesh, married women are more acceptable in politics than unmarried women. Therefore, the marital status of candidates can make a large difference during the election as it adds honor and respectability. While a married woman is regarded as capable and accountable, a single woman is viewed as careless and immature. Additionally, widows are usually accepted in the society if she has a good reputation. Unmarried women usually face social barriers while trying to participate in politics. Like an unmarried woman, divorced or separated women are less acceptable in the society as a political leader. However, this mindset is changing slowly.

\section{Number of Children with Age of the Women Participants}

Although marriage accords status to women who enter politics, it also burdens them with responsibilities that make participation in politics difficult, particularly for young mothers. Women in particular with young children find it hard to join politics due to lack of time and domestic errands. These responsibilities confine women within the home, keep them out of the labor force and restrict their interest and involvement in politics. Thus, women barely have time to talk about political affairs and acquire political experience [27].

Half of the federal women participants in Australia did not have any children at the time of their first election, and of those who did, only two had children under the age of 16 years. Among Australian local government participants, two of the participants contested with no children, and of those who did, only two had children under the age of 16 years.

The ABS reports show that in the course of recent decades, successive generations of Australian women are giving birth to fewer children, and are tending to have children at older ages. In 1981, women aged 40-44 years had an average of 2.8 children each (including women without children). By 2006 the average number of children 
had fallen to 2.1. The ABS has identified the progressive deferment of female's first birth as the reason of reduced fertility in recent decades. Delays in child-bearing lessen the rest of the time in which women can have children and increase their possibility of staying barren. Declining fertility levels over the lifetimes of consecutive cohorts of women in contemporary decades are closely related to specific cultural and societal changes in Australia and other industrial nations. Growing social liberalism (including the availability and accessibility of contraception) and economic deregulation has created scope for women to become more independent to control their fertility, while at the same time increasing the expenses of childbearing. Together with rising labor market opportunities, women are getting better education over time. Additionally, pursuing post-school education may lessen fertility as women are less likely to have children while studying, and upon finishing their studies, women may defer childbearing to build a career [28]. Additionally, a significant number of women in the Australian labor force are either childless or do not have young children. Thus, a woman without children is not uncommon in Australian society.

In Bangladesh, the social system is somewhat different; many people live in extended families, or there is support from relatives or house assistants. Among the women who contested at the national elections, three had adult children, three were mothers of adolescent children, and another two were mothers of pre-adolescent children, while two were without children. At the local government level, all women had children, and seven of them were mothers of infants or young children. On average, most of the women representatives in Australia and Bangladesh had two children.

Nahar claims that being childless has a wide variety of antagonistic outcomes for Bangladeshi women; be they individual, mental, financial or social, with the essence of these results being disadvantaged. Rural childless women particularly encounter strong stigma as their identity is undervalued for not being capable of giving birth; they are blamed for their sterility and consequently suffer from a sense of guilt. They are also socially secluded, and many times are abandoned by their families. They live a life full of panic and anxiety due to marital disturbance. The urban childless women, like their rural sisters, suffer from guilt and go through social isolation, loss of self-esteem and dishonor. Uncertainty and distraction in their relationships with their husbands are, nevertheless, less extreme than the rural infertile females [29].

\section{Occupation of the Women Participants before Getting Elected in Political Office}

Occupation is a major indicator of a person's financial status. It is claimed that higher female participation in the labor force increase opportunities for women to get nominated for electoral office and being elected as representatives [30]. All the federal and local level participants in Australia were engaged in paid work before being elected. Data on parliamentary website of Australia shows that all female federal parliamentarians (2013-2016) were involved in the formal job sector before being elected.

Among Bangladeshi participants, five women parliamentarians were involved in paid jobs, two were engaged in business, and three were housewives. It indicates that at the national politics women parliamentarians are mostly engaged in the professional job sector. However, among the local government participants in Bangladesh, six women representatives were homemakers while the other four were engaged in the professional job sector. Thus, in local government in Bangladesh, it is common to have many women who are homemakers before they join local government.

\section{Political Backgrounds of the Women Participants}

Political participation requires knowledge and interest in politics, participation in political activities and perception of political competence and efficacy. Therefore, it is important to know the political backgrounds of the women representatives.

\section{Involvement of Family Members in Politics/Political Position of the Women Participants}

Encouragement by family is an important factor for women who want to join politics. However, often an important factor in terms of a woman gaining acceptance from parties for nomination are the connections that her family have with the political establishment, including family members who serve, or have served previously, in influential political positions.

Brennan claims that politics in Australia is a family affair and several women have family connections with previous or current MPs or party officials. Some women served in the same seat as their father or husband. Since Federation there have been a number of political families in the Commonwealth Parliament. The first parliament included eight sons of state parliamentarians, and seven members who had brothers in state parliaments. Since 1901 until 2015 there were 30 occasions of son-father combination in the parliament and two occasions when a daughter succeeded her father. Of these, 14 were Labor Party supporters while 17 were non-Labor. In one unusual situation, a father succeeded his son in Parliament; when son Francis Matthew John Baker died in office, his father Francis Patrick Baker was elected to his seat. There are two incidents of three successive generations in the Commonwealth Parliament. A mother and daughter combination was elected to Australian parliaments: Elaine Darling (1980-93) is the mother of Vicky Darling 
(2006-12). Furthermore, there are husband-wife combinations in federal parliament. The first two women elected to the House of Representatives, were the widows of previous members. In recent times, Kevin Newman was a minister in the Fraser government while his wife Jocelyn served in the Howard government. In 2015 at least 12 members of the Parliament have, or have had, a relative in federal or state parliament [31-33].

However, it is found that the federal level participants of this study in Australia mostly do not have very close relatives in influential political positions. They are in politics because of their personal interest. Likewise, it cannot be assumed that female politicians with strong political backgrounds join politics only to maintain family traditions, as they may also get interested in politics from being inspired by relatives. For example, Liberal Party MP Melissa Price, who is the fourth generation of her family in politics (her grandfather and uncle were state Labor parliamentarians), states that she got inspired to join politics after seeing her parents' involvement in the Labor Party [34].

Like federal parliamentarians, female participants at the local level in Australia have no close relatives in politics. Only two had their fathers served as local councilors. The family is essential in politics everywhere throughout the world, for both genders. Actually, political dynasties are not uncommon in the industrialized West. However, the influence of family may be greater in the context of developing countries. In developing countries, it is usually seen that women's participation in politics is generally influenced by their family members' attachment in politics. In Bangladesh, like other developing nations, it is very common that the female political leaders are the daughters, daughter-in-laws, and grand-daughters or close relatives of some well-known political figures.

Eight of the female parliamentary participants in Bangladesh are from politically influential families. In addition to their personal reputation, their family backgrounds have helped a lot to be nominated and/or elected. Family ties are a vital source of individual power in Bangladesh. The sitting Prime Minister Sheikh Hasina and the Opposition Leader Khaleda Zia came to politics to substitute their assassinated father and husband respectively. Neither of them had any institutional background in politics. Not just the Prime Minister and the Opposition Leader, a large number of female MPs came through family networks. There were three couples as MPs in the parliament (1996-2001). In the general election, one candidate may contest for five constituencies. When he/she wins more than one seat, he/she keeps one seat and by-elections are held for the other seats. All three couples used this chance, and their wives vied and won the seat vacated by their husbands in the by-elections [35]. Further, several female MPs in the parliament are substitutes for male family members who were formerly involved in politics, but for a number of reasons like detention or corruption allegations are declared ineligible to stand in the election [36].

In local government in Bangladesh, all except two of the participants have close relatives in politics, and the relatives have played a major role in their political career. Likewise, Islam found that all the female urban local government representatives had kin relations with MPs, the vice-president, mayors, other ward commissioners and influential party members. Regular and intimate contacts with these people have helped and inspired them to join politics. Family connections are so strong that even if they belonged to different political ideologies, they were backed by the relatives to get elected [17].

Thus it can be said that social status, participation in anti-government movements, and links to politically influential male relatives are vital factors for women's political participation in Bangladesh, but not so much for Australia.

\section{Type of Seats Contested by the Women Participants}

While in Australia women stand against men in the same types of seats, the reserved seat system in Bangladesh means that women have a choice whether to run against men for general wards or seek office in reserved seats. In Bangladesh, only three women participants contested in a direct election, and one of them was defeated. The rest of the female legislators are in the parliament by contesting in the reserved seats for women. Eight of the female representatives in Bangladesh did not vie in any direct election, rather were elected to the reserved seats.

As the general seats in local and national governments in Bangladesh are very competitive, women find it difficult to win. So they prefer to contest in the reserved seats. The reserve seat selection at the parliament is made after the national election when the majority parties call for applications from interested female candidates to contest for the reserved seats. After the initial selection, candidates face an interview board to justify why the party should nominate her, description of her contribution to party politics, the way she intends to manage her constituency and so on. At the end, the top leaders of the political parties make the final selections. Following party nomination, names of the selected candidates are put forward formally to the Election Commission (EC). The EC officially announces the last date for withdrawal of nominations, and after the expiry of the withdrawal date, the EC declares the result and publicizes the names through gazette notification [37]. At the local government, one-third of the total seats are reserved exclusively for women where they vie against other female candidates to get elected by direct voting. 


\section{Length of Experience of the Women Participants as Elected Representatives}

Women in federal parliament in Australia tend to have experience in contesting more than one election, which is an indication of their degree of dedication to forging a career in politics. One has been in parliament for 20 years while another for 17 years without any break. Five participants in Australia have served in the legislature for more than a decade. There are only two who are fresh entrants in the parliament. In addition, four have experience contesting at local and state elections.

When compared against the experience level of female federal politicians generally, the sample of the participants has a higher proportion of experienced representatives. It is found from the parliamentary website on Australia that amongst the female parliamentarians (2013-2016), 22 are first time entrants in the federal parliament, 16 have served for two terms, nine for three terms, six have the experience of working for four terms, four have served the job five terms, three have been there for six terms, another three for seven terms, and one has served parliament for 10 terms. In addition, four have the experience of contesting and/or serving the state parliament, and six have served in local government [15]. Like the federal level participants, women at the local government in Australia also tend to have experience of contesting more than one election. Only two stood for local election for the first time. Three women also vied in state or federal election and were defeated.

In Bangladesh national parliament, three of the participants are serving for six years; six have served a five-year term, and one is fresh. All are elected to the reserved seats. Likewise, the majority of the female parliamentarians in the current parliament are from the reserved seats. Thirty-nine for the first time, eight for the second term and one is serving as MP from reserved seats for four terms [13]. At the local government, four participants had experience of serving the local government for more than a decade. However, all except one are in reserved seats. Five have been in local government as reserved councilors for more than four years, and one has been there for one year.

It is seen that women in federal politics in Australia have more experience than women in local government in Australia and women in national and local politics in Bangladesh. On the other hand, women in local government have more or less similar length of service in Australia and Bangladesh. Like federal representatives, women participants at local government in Australia mostly have experiences of serving on councils for more than one term, while $30 \%$ of the female participants are fresh on the council. On the other hand, in Bangladesh half of the interviewees are serving first term in the council and are elected in the reserved seats through direct election. It is found that participants in Australia have, in general, served in office more than participants in Bangladesh.

\section{Position in the Political Party Occupied by the Women Participants}

The position in a political party is an important indicator of women's political power. Women worldwide, in general, are marginalized in the party structure. However, the participants at national politics in Australia and Bangladesh hold important positions in the party. Available information on the parliamentary website of Australia gives the impression that all female members and senators have experience of serving important party positions. It is uncertain how many of these positions actually constitute powerful positions.

Local government elections in Western Australia are non-aligned political parties. It is found that all but one Australian participant is non-aligned to any political party. One representative is an ex- member of the National Party. Another is an ex-member of the Liberal Party, and one is an ex-member of the Greens Party. The participants generally held the view that party politics in local government is insignificant as councils deal with matters that are apolitical.

Among Bangladeshi participants in national politics, all are actively engaged with party politics and hold important posts; all except two have considerable political experience as they were active in student politics and gradually got engaged in national politics. However, all the female parliamentarians are politically well connected. Among Bangladeshi participants in local government, four women are actively engaged with party politics while another two were involved in political parties without any position. The cabinet of Bangladesh has approved to conduct local government elections in Bangladesh on party symbols from December 2015, but at the time of this study, local government representatives were non-aligned with national political parties. In Bangladesh involvement with a political party helps one to get elected. Among the participants of the study, seven occupy positions in political parties while the rest are supporters of either the ruling party Awami League or Bangladesh Nationalist Party (BNP). Although the local government election in Bangladesh was apolitical until recently, political affiliation helps one get elected.

\section{Discussion on the Findings}

Therefore, it can be surmised that female participants at the national level in Australia and Bangladesh have much in common regarding their socio-economic and political backgrounds. Overall, women in these two countries are middle-aged, mostly married, have children, have a tertiary education, come from the formal job sector like law, consultancy, business or teaching, have had previous political involvement, and seek to be re-elected and acquire a higher 
political position. However, fewer Australian participants at the national level are married, and they have fewer children than female legislators in Bangladesh. Also, in contrast to the Australian participants, Bangladeshi participants tend to come from families that have other members involved in politics, hence continuing something of a political dynasty. The average legislative experience for Australian participants is 9.25 years while for Bangladeshi participants the average experience is 4.9 years.

The differences between Australian and Bangladeshi participants at local government are more distinct. The current age distribution of the participants indicates that the majority of Australian participants are, like national participants in both Australia and Bangladesh, 40+ years of age. In contrast, the majority of participants in Bangladesh are in their 30s. Like national participants in Australia, Australian local government participants are less likely to be married than Bangladeshi participants. Australian local government participants, like Australian and Bangladeshi parliamentary participants, are all involved in the professional job sector, whereas in Bangladesh, the majority are homemakers. All Australian local government participants are, like national participants in both Australia and Bangladesh, have completed tertiary education, but only $40 \%$ of Bangladeshi local government participants have a tertiary education.

One noteworthy distinction between national and local government participants is that, whereas participants at the national level in Australia and Bangladesh tend to have previous experience of student politics before joining politics, local government participants do not. Australian local government participants joined politics mostly as they were unhappy with their councils, while in Bangladesh, most women joined because of family connections or inspiration from others (also an important factor for Bangladeshi parliamentary participants). Unlike Australian participants, almost all legislators and local government participants in Bangladesh have close relatives in influential political positions that have helped them to join politics.

\section{Barriers to the Political Participation of Women}

The interviews with the participants explored several impediments to the political participation of women. All the participants identified the domestic role of women as one of the most complex impediment causing women's underrepresentation in politics. Due to the domestic responsibilities, many women have entered politics once their children are grown up. Entering politics late may hinder women's promotion and prospects to high positions of influence.

Lack of education is another barrier that impedes political participation of women. While women on the whole in Australia do not face the problem, in Bangladesh, many girls do not get the opportunity to attend schools after primary level (grade/year V). Lack of finance is another issue that women in general encounter. Women in both Australia and Bangladesh find it difficult to manage the huge amount of money required to vie in the national election. Additionally, harassment and bullying deter women from participating in politics in Australia and Bangladesh. Furthermore, political violence that is very common in Bangladesh and lack of security discourage many eligible and interested women to get involved in politics.

Politics is male-dominated. The legacy of male-domination results in lower interest and involvement of women in politics, which tends to be viewed as a "man's domain." Women in both countries have recognized the aggressive and masculine nature of politics and the lack of party support as major political hindrances to women.

The participants identified the traditional division of labor, peoples' attitudes towards women in society, and the socialization process as most critical socio-ideological barriers to the political participation of women. Popular attitudes towards women's primary roles as mothers and homemakers all around the world restrict women from participating in the public sphere. In addition, the traditional gender roles and socialization cause low self-confidence among women that inhibit their participation in politics in both countries.

Moreover, religion plays a strong role in the lives of women in Bangladesh. Due to religious customs people in Bangladesh, in general, prefer women confined within the domestic spheres; women are deprived of property rights that impede their entry into politics. In contrast, in Australia, the media plays a crucial role in shaping political participation of women in federal politics. The media tends towards negative reporting about female politicians; focusing on their appearance and personal life in a way that male politicians are not subject of.

The obstacles to the political participation of women at the national and local government in both Australia and Bangladesh are mostly alike except for a few differences related to the contrasting political and cultural contexts. It is found that family responsibilities, traditional gender roles, lack of resources, attitudes of broader society towards women, the aggressive nature of politics, and the chauvinistic attitudes of male colleagues present challenges to women when considering politics as a career. This implies that there is a set of common issues that transcends socio-cultural differences. However, it is also the case that the same barriers differ between the two countries in terms of degree, and this aspect might be attributable to modernization effects. 


\section{The Effect of Modernization}

Bangladesh is a partial democracy; this country is suffering due to wide scale corruption, lack of transparency and accountability, poor governance, lack of independence of the media, the absence of rule of law and limited human rights. Islam influences and shapes everyday life of people in Bangladesh. Men determine women's role in the household economy, their decision-making power, mobility, attitudes, and marriage and childbearing patterns all. The recent policies and activities of government have helped to increase female adult literacy rates that can be explained as a positive impact of modernization that causes a shift in social norms regarding women in society. However, modernization is still flourishing in the country. Extended families are common both in urban and rural areas although in the cities, nuclear families are increasing. In the social context of Bangladesh, getting married, having children are normal practices for a woman. Due to the traditional customs and norms, men are given priority over women; women are viewed as their properties. Men use violence to control and show their supremacy over women.

On the other hand, Australia is an old-established democracy. Modernization brings significant changes in the lives of people; homosexuality, abortion all are accepted. Individualization is strengthened by the gender revolution due to modernization. People have rights to make individual decisions about their life. However, the importance of the media and issues concerning confidence and anxiety are consistent with contemporary challenges in countries like Australia.

Modernization fosters social and political transformations that result in changes in employment and the occupational structure, the expansion of the service industries, rising unemployment, and lower retirement ages [38]. Modernization causes not just structural change, rather a changing relationship between social structures and social agents. When modernization reaches a certain level, agents tend to become more individualized, that is, less constrained by structure. The resultant individualization opens up a situation where individuals make decisions about whether and whom they will marry, whether they will have children, what sort of sexual preference they might have. Individuals must then, free of these structures, reflexively construct their own biographies [39]. Growing individualization together with an accompanying stress upon lifestyle, consumption and choice are the resultant outcomes of modernization in the West [38]. Thus, in the post-industrial society, while modernization expands opportunities for women, destabilizes patriarchy, and allows women greater access to education and jobs, it may increase the risks for women by relieving men of their parental duties and make women entirely responsible for child-rearing. Consequently, a financially disadvantaged singleparent family might increase where women have to live with emotional and monetary stress as a single-parent; and struggle to juggle individual responsibility for their professions with their duties to their children [40]. It is found that over the last few decades, single-parent families have increased in Australia. A larger number of children are now living with a lone parent, mostly with mothers, often in financial crisis. According to ABS, $15 \%$ of all families in Australia are one parent families; single mother families constitute $81 \%$ of lone parent families [24], that can be explained as the result of modernization.

The available data indicates that women's participation in national parliament and local government are almost similar both in Australia and Bangladesh. However, most of the women in Bangladesh are elected to the reserved seats. When the quota effect is factored in, there is quite a divergence in the participation rates of women in politics between the two countries, and this is linked to the strength of the barriers that are operating. While women in both countries encounter many similar obstacles, they are more acute in Bangladesh, experiencing less support from male colleagues; greater financial challenges, less public support; more dependence on family support. All these can be viewed as symptoms of the different stages of development in Australia and Bangladesh along the modernization continuum.

What is interesting, however, is that in most cases the obstacles do not simply disappear as a country becomes more modernized, but continue to exert themselves, despite trends towards liberalization and gender equality. It is found that patriarchy ("traditional" culture of male-domination) which are deep-rooted in the culture regarding the division of sex roles prevailing for many years is responsible for the resemblance of impediments to women in the two countries irrespective of differences in the level of modernization.

\section{CONCLUSION AND RECOMMENidATION}

Industrialization creates increased job opportunities for women. More women are now getting an education and are involved in the labor market. However, women are still juggling to balance professional and family demands in both Australia and Bangladesh. The domestic responsibilities make their involvement and participation in the public sphere difficult. It seems that modernization does not necessarily wipe away the traditional attitudes towards women regarding their duties at home as mothers and wives. Indeed, women in modernized societies are participating in the labor force as well as performing their household duties. Patriarchy prevails in both countries and creates difficulties to their political participation.

It can be said that modernization has helped to remove many of the patriarchal restrictions on women and foster changes in peoples' attitudes regarding gender roles. However economic liberalization has not led automatically to liberalized attitudes in the socio-cultural sphere, particularly in the last bastions of patriarchal control such as the formal 
political arena. There has been a transformation to more equality, but it has been slow and hard-going and does not appear to have been as closely tied to modernization as the modernization proponents would suggest. The following recommendations need attention to improve the situation:

- The political parties need to encourage, attract, support, train and mentor more women, especially young women. Political parties should initiate affirmative action policies like introducing quotas for women. The parties can play a stronger role by selecting an equal number of women in the party structure as well as in the nomination. In addition, political parties need to address gender biases.

- It is necessary to change the aggressive nature of politics.

- Financial support should be offered to women in need while campaigning for election.

- The government should ensure more women in decision-making and other senior positions in business, trade unions and all other sectors where women might make a transition into politics.

- Cooperation from family members, especially husband and in-laws is vital for women to participate in politics. Family members can look after the children and supervise household activities so that interested women can manage time for politics. More women-friendly policies like free childcare centers, convenient meeting time and ways of overcoming domestic responsibilities are required.

- A change in the attitudes of society is a must; for example, men need to be more accepting of women working full time, and accepting that housework and child-care should be equally distributed.

\section{REFERENCES}

1. Bari, F. (2005). Women's political participation: Issues and challenges. Paper presented at the expert group meeting on enhancing participation of women in development through an enabling environment for achieving gender equality and the advancement of women, Bangkok, Thailand. Retrieved 14 August 2008 from http://www.un.org/womenwatch/daw/egm/enabling-environment2005/docs/EGM-WPD-EE-2005-EP.12\% 20\%20draft $\% 20 \mathrm{~F} . p d f$

2. Verba, S., \& Nie, N. H. (1972). Participation in America: Political democracy and social equality. New York: Harper \& Row.

3. Wolfinger, R. E., \& Rosenstone, S. J. (1980). Who votes? (Vol. 22). New Haven, Connecticut: Yale University Press.

4. Burns, N., Schlozman, K. L., \& Verba, S. (2001). Private roots of public action: Gender, equality, and political participation. Cambridge, MA, USA: Harvard University Press.

5. Bossen, L. (1975). Women in modernising societies. American Ethnologist, 2(4), 587-601. doi:10.1525/ae.1975.2.4.02a00010

6. Kenworthy, L., \& Malami, M. (1999). Gender inequality in political representation: A worldwide comparative analysis. Social Forces, 78(1), 235-268. doi:10.1093/sf/78.1.235

7. Reynolds, A. (1999). Women in the legislatures and executives of the world: Knocking at the highest glass ceiling. World Politics, 51(4), 547-572. doi:10.1017/S0043887100009254

8. Rule, W. (1981). Why women don't run: The critical contextual factors in women's legislative recruitment. Political Research Quarterly, 34(1), 60-77. doi: 10.2307/447890

9. Inglehart, R., Norris, P., \& Welzel, C. (2002). Gender equality and democracy. Comparative Sociology, 1(3), 321345. doi:1163/1569133021 00418628

10. Jaquette, J. S. (1982). Women and modernisation theory: A decade of feminist criticism. World Politics, 34(2), 267284. doi:10.2307/2010265

11. Inter-Parliamentary Union [IPU] (2017). Women in national parliaments: World classification. Retrieved 21 July 2017 from http://www.ipu.org/wmn-e/classif.htm

12. United Nations Development Program [UNDP]. Women's representation in local government in Asia-Pacific status report 2010: Going beyond national targets in monitoring status for MDG 3 on women's political empowerment $\begin{array}{lllll}\text {.Retrieved } & 18 & \text { June } & 2014 & \text { from }\end{array}$ http://Www.Capwip.Org/Readingroom/Topotheshelf.Newsfeeds/2010/Women's\%20particiipation\%20in\%20local\% 20government-Asia\% 20pacific\%20 (2010).Pdf

13. Bangladesh Parliament. (n.d.). List of 10th Parliament Members. Government of Bangladesh. Retrieved 5 November 2015 from http://www.parliament. gov.bd/index.php/en/mps/members-of-parliament/current-mp-s/listof-10th -parliament-members-english

14. Desposato, S. W., \& Norrander, B. (2005). The participation gap: Systemic and individual influences on gender differences in political participation. Paper presented at the annual meeting of the Western Political Science Association. Retreived 10 April 2013 from http://www.eldis.org/go/ home\&id= 33161\&type=Document\#.WPWtddKGPIU

15. Parliament of Australia. (n.d.). Senators and Members. Retrieved 5 November 2015 from http://www.aph.gov.au/Senators_and_Members

16. Irwin, M. R. (2001). State of women in urban local government: Australia. Paper presented at the Asia-Pacific Summit of women mayors and councillors. Phitsanulok, Thailand. Retrieved 25 December 2011 from http://www.capwip.org/readingroom/australia.pdf 
17. Islam, F. (2002). State of women in urban local government Bangladesh. Paper presented at the Asia-Pacific Summit of women mayors and councillors. Phitsanulok, Thailand. Retrieved 24 October 2010 from http://www. capwip.org/readingroom/bangladesh.pdf

18. Verba, S., Schlozman, K. L., \& Brady, H. E. (1995). Voice and equality: Civic voluntarism in American politics. Cambridge, Mass: Harvard University Press.

19. Goetz, A. M. (2003). Women's education and political participation. Retrieved 3 June 2014 from http://unesdoc.unesco.org/images/0014/001467/146770e. pdf

20. World Economic Forum [WEF]. (2016). The global gender gap report 2016. Retrieved 8 August 2017 from http://www3.weforum.org/docs/GGGR16/WEF_Global_Gender_Gap_Report_2016.pdf

21. Sultana, A. (2010). Patriarchy and women's gender ideology: A socio-cultural perspective. Journal of Social Sciences, 6(1), 123-126.

22. Jennings, M. K. (1983). Gender roles and inequalities in political participation: Results from an eight-nation study. The Western Political Quarterly, 36(3), 364-385.

23. De Vaus, D. (2004). Diversity and change in Australian families: Statistical profiles. Melbourne: Australian Institute of Family Studies. Retrieved 24 January 2013 from https://aifs.gov.au/publications/diversity-and-changeaustralian-families.

24. Australian Bureau of Statistics [ABS]. (2016). Marriages and divorces, Australia, 2015. Australian Government. Retrieved 17 January 2017 from http://www.abs.gov.au/ ausstats/abs@.nsf/mf/3310.0

25. Woodward, M. E. (2013). Ditch the witch: Julia Gillard and gender in Australian public discourse (Honours thesis), University of Sydney, Sydney. Retrieved 30 July 2015 from http://ses.library.usyd.edu.au/bitstream/2123/9554/1/Woodward,\%20M_GCST_HonoursThesis_2013

26. Shamim, I., \& Kumari, R. (2002). Gender and local governance. Retrieved 7 February 2009 from http://saneinetwork.net/Files/02_06.pdf

27. Schwindt-Bayer, L. A. (2011). Women who win: Social backgrounds, paths to power, and political ambition in Latin American legislatures. Politics and Gender, 7(1), 1-33. doi:10.1017/S1743923X10000541

28. Australian Bureau of Statistics [ABS]. (2009). Australian social trends, 2008. Australian Government. Retrieved 17 November 2016 from http://www. abs.gov.au/ ausstats/abs@.nsf/Lookup/4102.0main+features12008

29. Nahar, P. (2010). Misery of empty laps: Life of childless women in Bangladesh. Facts, Views \& Vision : Issues in Obstetrics, Gynecology and Reproductive Health, 28-34. Retrieved 8 April 2016 from http://www.fvvo.be/ assets/ 129/15-Nahar.pdf

30. Stockemer, D. (2015). Women's descriptive representation in developed and developing countries. International Political Science Review, 36(4), 393-408. doi:10.1177/0192512113513966

31. Brennan, D. (2006). Women in the "Bear Pit." Paper presented at the Australasian Political Studies Association conference University of Newcastle, Australia. Retreived 8 July 2016 from http://citeseerx.ist.psu. edu/viewdoc/download? doi=10.1.1.528.5362\&rep=rep1\&type=pdf.

32. Grattan, M. (2010, October 24). It's all relative - mother and son first a new link in a tradition of generations. The Sydney Morning Herald. Retrieved 7 January 2017 from http://www.smh.com.au/federal-politics/politicalopinion/its-all-relative--mother-and-son-first-a-new-link-in-a-tradition-of-generations-20101023-16ygy.html

33. Gobbett, H., \& Lumb, M. (2015). Parliamentary relations: Political families in the Commonwealth Parliament. Department of Parliamentary Services, Parliament of Australia. Retrieved 8 August 2017 from http://www.aph.gov.au/About_Parliament/Parliamentary_Departments/Parliamentary_Library/pubs/rp/rp1516/ParlR el

34. Yaxley, L. (2014, December 19). MPs' former lives: The quirky backgrounds of Australia's federal politicians. ABC News. Retrieved 20 september 2017 from http://www.abc.net.au/news/2014-12-18/the-former-lives-of-austra lianpoliticians $/ 5973234$

35. Halder, N. (2004). Effective representation of women legislators in parliaments: A case study of New Zealand in theoretical and global perspectives (PhD thesis), University of Canterbury, New Zealand. Retrieved 13 August 2015 from http://ir.canterbury.ac.nz/handle/10092/4780

36. Hossain, N., \& Akhter, S. (2011). Gender, power and politics in Bangladesh: A baseline study for the upazila support project. Retrieved 3 June 2014 from http://ndc.gov.bd/lib_mgmt/webroot/earticle/517/Gender_power _politics_in_BD.pdf

37. Firoj, J. (2007). Women in Bangladesh parliament: A study on opinions of the women MPs. Dhaka: AH Development Publishing House.

38. Elliott, A. (2003). Critical visions: New directions in social theory. Mitchellville, Maryland: Rowman \& Littlefield.

39. Lash, S., \& Wynne, B. (1994). Introduction. In M. Ritter (Ed.), Ulrich Beck, "Risk Society, Towards a New Modernity" (pp. 1-9). London, Newbury Park, New Delhi Sage publications.

40. Jarvis, D. S. L. (2007). Risk, globalisation and the state: A critical appraisal of Ulrich Beck and the world risk society thesis. Global Society, 21(1), 23-46. 